\title{
Circulating DNA-Important Biomarker of Cancer
}

\section{Dachuan Jin ${ }^{1 *}$, Suqing $\mathrm{Xie}^{2}$, Zhicheng $\mathrm{Mo}^{3}$, Yingjian Liang ${ }^{4}$ Baoqiang Guo ${ }^{5}$, Gengming Huang ${ }^{6}$ and Jianli Dong ${ }^{6}$}

${ }^{1}$ University of Texas Health Science Center at San Antonio, Texas

${ }^{2}$ New York Medical College at Valhalla, USA

${ }^{3}$ Conemaugh Memorial Medical Center, USA

${ }^{4}$ St.Elizabeth's Medical Center, Boston, MA, USA

${ }^{5}$ School of Medicine, The University of Manchester, UK

${ }^{6}$ University of Texas Medical Branch at Galveston

\begin{abstract}
Circulating extracellular nucleic acids, especially DNA, was discovered more than sixty years ago, but it is becoming hot just in the last two decades because it is now widely recognized as a very promising biomarker for the early diagnosis, monitoring, and evaluation of prognosis of cancer. In addition, compared with traditional surgical approaches and other biochemical tests, circulating DNA as a biomarker, owns many obvious advantages. It is easily accessible, reliable, reproducible and early detectable in cancer. It is also very sensitive and specific if cancer specific DNA alterations are tested instead of elevation of circulating DNA concentration. But the clinical application of this biomarker is still just limited to obstetrics and prenatal diagnosis. This review throws light on its history, current research update and potential clinical application in cancer diagnosis and management. In addition, major detection technologies of circulating DNA are summarized concisely and comprehensively.
\end{abstract}

Keywords: Circulating DNA; Extracellular; Cancer; Biomarker; Diagnosis; Prognosis; Cell-surface-bound

\section{Circulating DNA \& Cancer}

Circulating DNA as a very ideal non-invasive biomarker can easily be isolated from human plasma, serum and other body fluids [1]. Small amounts of free DNA circulate in both healthy and diseased human plasma/serum, but increased concentrations of DNA present in the plasma of cancer patients and miscellaneous diseases and physiological conditions, such as pregnancy, tissue trauma, Systemic Lupus Erythematosus (SLE), rheumatoid arthritis, glomerulonephritis, pancreatitis, cholelithiasis, inflammatory bowel disease, peptic ulcer disease, hepatitis and esophagitis [2,3]. This review discusses the progress of circulating DNA research and its application in diagnosis, monitoring and therapeutic application of cancer.

\section{Categories of Circulating DNA}

Circulating cell-free DNA: In 1948, only a few years after the demonstration of DNA is the material of inheritance, the circulating nucleic acids including both DNA and RNA, in human blood plasma were discovered by Mandel and Metais [4]. As they reported, the mean quantity of plasma circulating DNA was approximately $1 \mathrm{mg} / \mathrm{L}$, but the level in later researches varied from less than $10 \mathrm{ng} / \mathrm{ml}$ to more than $1500 \mathrm{ng} / \mathrm{ml}$ [4-9].

It has been more than seventy years, but the origin of circulating cell-free DNA is still not clear. There are some possible origins of circulating cell-free DNA have been postulated, which include apoptosis, necrosis, active release of free circulating DNA by living cells [10-12] e.g. human lymphocytes have been shown to release DNA in the absence of any stimulation, which is regulated by a homeostatic mechanism $[13,14]$. Since significantly elevated levels of circulating cell-free DNA have been found in many studies and in patients with several cancer types, one has to consider that an undefined part of DNA present in the circulation is of non-tumor origin [15].

Circulating cell-surface-bound extracellular DNA: Circulating extracellular nucleic acids not only circulate in the plasma fraction of blood, but also are bound at the surface of blood cells. Tamkovich et al.
[16] found that the main part (98\%) of circulating DNA in the blood of healthy donors is bound to the surface of erythrocytes and leukocytes and the concentration of cell-surface-bound circulating DNA depends on the patient's gender. But in the blood of cancer patients, extracellular nucleic acids were found in plasma and not at the $[16,17]$ cell surface. In patients with nonmalignant breast tumors, extracellular nucleic acids were found both at the surface of blood cells and in plasma [16].

Rykova et al. [17] found that methylated DNA could be detected in the circulating extracellular DNA eluted from the surface of erythrocytes and leukocytes, even in the samples where no methylated DNA could be detected in plasma. Therefore, circulating extracellular DNA bound to cell surface was considered to be a valuable source of material for early noninvasive cancer diagnostics and monitoring.

\section{Potential Clinical Significance of Circulating DNA in Cancer}

Circulating DNA is now utilized widely as a genetic biomarker in a variety of pathological conditions, mainly in cancerous conditions [18]. It is reported to be a useful biomarker for various types of cancer, such as lung, prostate, testicular and ovarian cancer [19-23]. It is used as a diagnostic tool and useful surrogate biomarker for therapeutic response [24,25]. Mutations, methylation, DNA integrity, microsatellite alterations and viral DNA have been detected in circulating cell-free DNA in blood of patients with cancer. In addition, changes in the levels of circulating nucleic acids have been associated with tumor burden and malignant progression [26].

*Corresponding author: Dachuan Jin, University of Texas Health Science Center at San Antonio, Texas 78229, USA, Tel: (832) 564-9081; E-mail: dachuanjin@gmail.com

Received April 19, 2012; Accepted May 02, 2012; Published May 07, 2012

Citation: Jin D, Xie S, Mo Z, Liang Y, Guo B, et al. (2012) Circulating DNA-Important Biomarker of Cancer. J Mol Biomarkers Diagn S2:009. doi:10.4172/2155-9929.S2009

Copyright: (c) 2012 Jin D, et al. This is an open-access article distributed under the terms of the Creative Commons Attribution License, which permits unrestricted use, distribution, and reproduction in any medium, provided the original author and source are credited 
Alterations in total cell-free circulating DNA levels: The circulating DNA concentration in normal blood plasma is low, however, it is significantly increased in blood of cancer patients [27,28].

Recently, IIZUKA etc. report that cell-free DNA levels were significantly higher in the sera from Hepatocarcinoma patients than in the sera from HCV carriers or the control subjects. They find that cell-free DNA levels were associated with the degree of tumor differentiation and size, but not related other factors, including TNM (tumor lymph nodes)- stage or levels of Alpha-Fetoprotein (AFP), etc. [29]. Hence cell-free DNA levels in HCV (Hepatitis C virus)-related HCC (Hepatocarcinoma) patients could be used as a marker for the detection of early-stage small HCCs [29]. Jiang et al. [30] studied 66 AML (Acute Myeloid Leukemia) patients and 100 controls, and 20 cases of solid tumors, they found the level of plasma cell-free DNA in AML patients were significantly higher than those in other groups and the level in male was significantly higher than female patients. It is concluded that the quantification of plasma DNA may be useful for evaluating therapeutic effects and monitoring relapse in AML patients [30].

Previous reports suggest that a higher concentration of circulating cell-free nucleic acids correlates with disease progression or a higher tumor burden of solid tumors [31].

Circulating DNA could also be used for both clinical prognostication and monitoring during follow-up because the levels of circulating DNA would decrease after successful anticancer therapy $[26,30,32,33]$. It was even reported that plasma DNA levels was closely associated with cancer stage in non-small-cell lung cancer, which is the most common type of lung cancer, mainly include adenocarcinoma, squamous cell carcinoma and large cell carcinoma. Patients with higher circulating DNA levels had significantly reduced probability of long-term survival. Similar findings were reported in leukemia patients $[34,35]$. But the test criteria, sensitivity and specificity prevented it from becoming a clinical routine application for decades [36]

Chromosomal Mutations in oncogenes and tumor suppressor genes: Cancer is characterized by an accumulation of genetic changes. Chromosomal abnormalities, including mutations, insertions, deletions, allelic losses of oncogenes and tumor suppressor genes, microsatellite alterations, and so on, have been discovered in cancer cell DNA [37].

Several studies have demonstrated that plasma or serum of cancer patients contains significant amounts of circulating cell-free DNA, which often carries mutations and epigenetic alterations identical to those detected in tumor tissues. It has the potential to serve as biomarker in cancer subjects [38]. The first mutational analyses performed on plasma cell-free DNA concentrated on the K-ras and N-ras oncogenes [39-42]. N-ras mutation was detected in patients with myelodys plastic syndrome and acute myelogenous leukemia. In patients with $\mathrm{N}$-ras alterations, mutant DNA was always present in plasma DNA, though sometimes absent in the DNA of peripheral blood cells or bone marrow. Therefore, plasma cell-free DNA could be a better template than bone marrow or peripheral blood cells [39].

Microsatellite alterations: Microsatellites are stretches of DNA in which a short motif (usually 1-5 nucleotides long) is repeated 5-100 times, which are at high risk for variations in the number of repeats. These kinds of errors are normally repaired by Mismatch Repair System (MMR). The MMR system is often defects in cancer, which are one of the important carcinogenesis [43]. Microsatellite alterations include microsatellite instability and loss of heterozygosity. (a) Microsatellite Instability (MSI): it can be detected in free cell-free DNA, and may play an important role in cancer diagnosis and prediction of disease progression. Surprisingly, Schwarzenbach et al. [44] assessed the blood serum of 34 patients with primary and metastatic breast cancer and found that circulating tumor DNA dose not reflect the presence of tumor cells in blood or the level of tumor-associated protein markers, such as CA 15-3 [44]. In Non-small Cell Lung Cancer (NSCLC), microsatellite alterations in tumor DNA have a potential prognostic role for disease recurrence. Ludovini et al. [45] found that microsatellite alterations occurred in at least one locus in NSCLC tumors. Significant associations was found between microsatellite alterations and squamous-cell histotype, and also significantly associated with recurrence of disease [45].

(b) Loss of Heterozygosity (LOH): Circulating tumor DNA markers for loss of heterozygosity appear to have prognostic significance when identified in primary tumors and serum and/or plasma from cancer patients [46]. LOH of DNA microsatellites occur commonly among various alleles at specific chromosome loci in melanoma, such as at $9 \mathrm{p} 21$, in primary melanomas. $\mathrm{LOH}$ on chromosome 6q occurs more frequently in thicker primary melanomas with more invasive tumor type. $\mathrm{LOH}$ on $10 \mathrm{q}$ has worse prognosis [47]. The presence of $\mathrm{LOH}$ in the serum of patients with advanced metastatic melanoma was associated with a poorer response to induction biochemotherapy and independently, with patient outcome. Circulating tumor microsatellites are serving as immediate determinants of disease progression and response to treatment [46]. $\mathrm{LOH}$ analysis of the cell-free DNA was also considered to be useful for the early diagnosis of mucosal malignant melanoma [48].

Rawnaq et al. [49] report that monitoring of loss of heterozygosity in serum microsatellite DNA among patients with gastrointestinal stromal tumors indicates tumor recurrence, and correlates with the tumor status [49]. Kakimoto et al. [50] did microsatellite analysis of serum DNA in patients with oral squamous cell carcinoma and found $90 \%$ patients showed microsatellite alterations in serum DNA identical to those in the corresponding tumor DNA. They found that blood testing for circulating tumor genetic markers may provide valuable prognostic information and a guide for future therapy [50]. Takagi et al. [48] applied LOH analysis of cell-free DNA in the plasma of 17 patients with mucosal malignant melanoma in the head and neck. Of the 17 patients, 4 patients had recurrence and/or metastasis, and all 4 of these patients were found to have $\mathrm{LOH}$ in at least one or more loci for any region.

(4) Hypermethylation of tumor suppressor genes: DNA methylation is an epigenetic characteristic associated with the silencing of gene expression. DNA methylation is one of the most common molecular alterations in human neoplasia [51]. In cancer, aberrant DNA methylation is often found in the promoter region or at regulatory sites of genes which are involved in cell cycle regulation, growth or apoptosis [52].

Aberrant methylation of tumor suppressor genes is a more specific and common event in miscellaneous cancers, including breast cancer, pancreatic cancer, bladder cancer, lung cancer, and head and neck cancer, and so on [53]. While no single point mutation is common to every tumor type, aberrant DNA methylation patterns suggest that detecting disease early through observation of altered methylation patterns may be possible. Many tumor suppressors classically identified through mutation analyses, such as APC [54,55], BRCA1- breast 
cancer type 1 susceptibility protein $[7,56]$, cyclin-dependent kinase inhibitor $2 \mathrm{~A}[57,58]$, etc.. It has been shown to be a promising marker to detecting cancers in early stage $[59,60]$. DNA hypomethylating reagents such as azacitidine and decitabine, known to be DNA Methyl Transferase inhibitors (DNMTi) have recently come to be considered as standard therapeutics for patients with aberrant methylation, like MDS (Myelodysplastic Syndrome) [51,61].

By detection of methylation status of p16 in HCC, cirrhosis, chronic hepatitis, primary biliary cirrhosis, autoimmune hepatitis, drug induced liver disease, fatty liver and normal liver tissues with methylation, specific polymerase chain reaction, Kaneto etc. found that aberrant methylation was detected in HCC $(72.7 \%)$ and cirrhosis (29.4\%) and chronic hepatitis (23.5\%). All of which were positive for HBV (Hepatitis B virus) or HCV infections. In contrast, methylation was not detected in any of other samples from non-viral liver diseases. This indicates that the epigenetic change may be related to hepatitis virus infections. In addition, they found that all samples with promoter methylation showed loss of expression of p16. They also found that the majority of patients with methylation positive HCC had loss of p16 expression with promoter methylation at the stage of chronic hepatitis without clinically detectable carcinoma. [62]. Similar results were also reported by a clinical study by Harder et al. [63]. Inactivation of p16 by hypermethylation is also an early event in some other cancers, including lung, colon, esophagus, and pancreas [64-67]. The accumulation of methylated cytosine in the ${ }^{\prime}$ CpG island of p16 is thought in a dose dependent manner because all methylation positive HCC showed complete loss of p16 expression while the majority of methylation positive cirrhosis and chronic hepatitis samples showed partial loss of expression. [62]. One possibility is that partial loss of p16 expression in cirrhosis and chronic hepatitis may be due to the heterogeneity of methylation, then progress to methylated alleles in HCC. Thus detection of p16 promoter methylation is a potential molecular biomarker to follow up patients with a high risk of developing HCC, such as those with HBV or HCV infections. [62].

APC and DAP-K (Death-associated protein kinase 1) promoter methylation were reported, that do not contribute to hepatocarcinogenesis and can't be used as marker for HCC surveillance or detection. GSTP1(Glutathione S-transferase P) promoter may serve as good marker for HCC, just like p16 [63]. Villar etc reported that TP53 R249S mutation can be detected in serum DNA in patients with aflatoxin exposure and hepatitis B virus infection, but interestingly, this kind of mutation also varied with season, which is most common between April and July [68].

Mirza et al. [69] determined hypermethylation of ER-beta (Estrogen receptor beta) and RAR-beta2 in breast cancer patients and found that there were significant correlation between hypermethylation of ER-beta and RAR-beta2 in tumors and paired sera circulating DNA. In addition, concurrent hypermethylation was associated with poor overall survival. Therefore, they suggest that ER-beta and RAR-beta2 in serum circulating DNA could be used to predict invasive ductal breast carcinoma. Concurrent ER-beta and RAR-beta2 methylation as well as loss of ER-beta expression may serve as a prognostic marker [69].

DNA hypermethylation is also frequently found in Colorectal Cancer (CRC). Methylation of Helicase-like Transcription Factor (HLTF) and Hyperplastic Polyposis 1 (HPP1) are potential and Carcinoembryonic Antigen (CEA) is an established prognostic factor in serum of patients with CRC [70]. Hypermethylation of CpG islands is a common epigenetic DNA modification in human cancers leading to transcriptional silencing and can already be detected in early stages of carcinogenesis [71]. Several serum circulating DNA methylation markers have been described as potential screening markers for early stages of CRCs in asymptomatic patients, like NEUROG1, SEPT9, HLTF (Helicase-like transcription factor), HPP1/TPEF (Hyperplastic Polyposis 1/Transmembrane Protein Containing Epidermal Growth Factor and Follistatin Domains) [72-74].Especially HLTF and HPP1/ TPEF, which have been found specifically in patients with CRC, and significantly correlated with tumor size, metastatic disease and tumor stage. HLTF hypermethylation in serum is an independent predictor of disease recurrence $[75,76]$.

Aberrations in the methylation status of noncoding genomic repeat DNA sequences and specific gene promoter region are also important epigenetic events in melanoma progression. Methylation profiling of melanoma has demonstrated inactivation of tumor-related genes by hypermethylation of $\mathrm{CpG}$ islands in the promoter region [77-82]. LINE-1 (Long Interspersed Nucleotide Element-1) hypomethylation and AIM1 (Absent in Melanoma-1) hypermethylation have prognostic utility in both melanoma patients' tumors and serum. LINE-1 became progressively hypomethylated during melanoma progression. LINE-1 hypomethylation level was higher in stage IV melanomas compared with other stages. Promoter hypermethylation of AIM1 downregulated AIM1 expression in natural killer-cell malignancies. AIM1 was significantly suppressed during melanoma progression.

(5) Viral DNA: In some malignant tumors which related closely with specific virus, determination of circulating viral-DNA will be a good choice to anticipate, diagnose, and monitor relevant conditions. For example, Epstein-Barr virus (EBV) is a ubiquitous herpes-virus that is present within the malignant tissue of a variety of lymphomas, such as Classic Hodgkin Lymphoma (CHL), Post-Transplant Lympho Proliferative Disorder (PTLD), extra nodal NK-T cell lymphoma and nasopharyngeal carcinoma [83-87]. So the presence of EBV within the lymphomatous node and the close proximity of the lymphoid and blood circulation indicate potential as a highly tumor-specific biomarker [88]. In addition, the circulating cellfree EBV-DNA (but not cell-associated EBV-DNA) reflects therapeutic response in EBV-associated lymphomas [88].

\section{Technologies used to detect alterations of circulating Cell- free DNA}

Development of sensitive and specific approaches to detect circulating tumor DNA in bodily fluids may help early diagnosis/ monitor of cancer and leading to comprehensive revolution.

Determination of circulating cell-free DNA or viral DNA levels: Various methods have been used to purify circulating cell-free DNA, including modified salting-out, chromatography resins, magnetic beads, or guanidium thiocyanate [89-91]. But recently, circulating DNA is more commonly purified with commercial kits, like QIAmp 96 spin blood DNA extractions kit (Supplied by Qiagen), QIAamp DNA Blood Mini Kit (supplied by Qiagen), [30,92,93] BILATEST DNA Kit, Quant-iT ${ }^{\mathrm{TM}}$ DNA High-Sensitivity Assay kit and a Qubit fluorometer (supplied by Invitrogen) [5]. Quant-iT ${ }^{\mathrm{TM}}$ DNA High-Sensitivity Assay kit is known for its reliability and very good reproducibility [94]. Automated isolated systems like MagNa Pure LC are better than manual methods and produces even higher products of DNA/RNA. Quantitative Real-Time Polymerase Chain Reactions (RT-PCR) is the next step to amplify and quantify the circulating cell-free DNA of interest $[9,88]$. 
Detection of circulating cell-surface-bound DNA: Because there are only weak interactions between extracellular DNA and cell surface, the extracellular cell-surface-bound DNA can be easily eluted with EDTA solution. The other part is tightly bound to cell-surface proteins, but can be eluted by mild trypsin treatment of the cells together with the polypeptides binding nucleic acids [96]

After cell-surface-bound extracellular DNA is eluted from the surface of erythrocytes and leukocytes with PBS-EDTA (Contain $5 \mathrm{mmol} / \mathrm{L}$ EDTA) solution and trypsin solutions, and then analyzed by methylation-specific PCR according to a modified protocol [97]. There is no correlation found between the ages of the patients and the concentrations of free or cell-surface-bound circulating DNA. But they found that total mean concentration of circulating cell-surface-bound DNA in blood was higher in healthy men $(1030 \mathrm{ng} / \mathrm{ml}$ of blood $)$ than in healthy women $(430 \mathrm{ng} / \mathrm{ml})$. There the sex of a patient should be taken into consideration when the concentration of cell-surface-bound DNA is determined for diagnostic purpose [17].

(3) Detection of genetic alterations of circulating cell-free DNA: The detection of tumor-specific DNA aberrations is the most specific approach to detect circulating DNA.

Bisulphite sequencing is considered to be the "gold standard" in cytosine-methylation pattern studies. However, such strategies are both time and labor consuming [98]. The accuracy, speed, efficiency, and cost-effectiveness of circulating cell-free DNA sequencing have been improved dramatically. The most effective approach developed to date is based on massive parallel sequencing of plasma DNA molecules [99]. Such as that from $454 \mathrm{LifeSciences/Roche,} \mathrm{allows} \mathrm{high-throughput}$ nucleotide sequencing of individual molecules [100-102]. The advent of massively parallel sequencing gives us a quantitative and powerful tool for studying DNA on a genome-wide level and allows us to identify tumor-associated chromosomal translocations in plasma. These new technologies are capable of sequencing lots of DNA, all at once, which means that many pieces of DNA are sequenced at the same time. This provides new modalities for molecular diagnostics [103].

Serre et al. developed a new MBD (Methyl CpG Binding Domain)isolated genome sequencing technique, which provided a highthroughput and comprehensive survey of DNA methylation in the human genome. This could be a very useful technique in detection of methylation in circulating DNA in human bodily fluids.

The number of mutant gene fragments is small compared to the number of normal circulating DNA fragments, making it difficult to detect and quantify them with sufficient sensitivity for meaningful clinical use. Recently a new extraordinarily sensitive mutation detection technology called BEA Ming was reported. BEA Ming stands for Beads, Emulsions, Amplification and Magnetics. It is to perform singlemolecule PCRs on magnetic beads in water-in-oil emulsions with the core process of transformation of a population of DNA molecules into a population of beads each coated with thousands of copies of identical sequence [104]. The kind of technology has unparalleled sensitivity (detect and enumerate mutant and wild-type DNA when present at ratios greater than $1: 10,000)$ and selectivity (100-fold higher than conventional technologies) [105].

BEA Ming approach consists of four steps: (1) Real-time PCR is used to determine the number of gene fragment of interest in the plasma; (2) BEA Ming is used to convert the amplified plasma DNA into a population of beads; (3) The mutational status of the extended bead was determined by single base extension; (4) Flow cytometry is used to simultaneously measure the FITC, Cy5 and Phycoerythrin (PE) signals of individual beads. Diehl et et al. [103] analyzed 162 samples from 18 patients undergoing surgical therapy for primary or metastatic colorectal cancer, circulating tumor DNA was detected prior to therapy in $100 \%$ of patients. After surgical resection, the level of circulating DNA level fell reapidly [106].

Short Oligonucleotide Mass Analysis (SOMA) is the other methods for quantitative detection of mutations at selected positions [106]. In SOMA, small DNA fragments of interest are produced by PCR amplification and restriction digestion, and then characterized by HPLC-electrospray ionization mass spectrometry [38].

\section{Future Prospects}

Traditionally, tumor markers are proteins produced by tumor cells. The problem is only a subset of cancers would secrete specific proteins. Detections of circulating DNA or other nucleic acids will be a new generation of tumor markers because genetic aberrations are more frequently observed in cancers and directly involved in malignant development. In addition, it is a noninvasive biomarker that could accurately reflects status of conditions, which will be of great clinical benefit. Quantification of circulating DNA and identifying the frequencies of a variety of mutations, microsatellite alterations and status of gene promoter methylation are the main foci of research on circulating DNA.

Tumor-derived circulating cell-free DNA will be a very good marker for the anticipation, early detection, diagnosis, evaluation of prognosis, and monitoring of recurrence of various malignant neoplasms. With further prospective studies with large patient numbers, circulating cellfree DNA could be definitely clarified as part of the diagnostic screen in various human tumors.

The lack of uniformity in presenting and interpreting quantitative research data as well as the virtual absence of information regarding the structure and function of circulating DNA are considered as the main obstacle of prevent circulating cell-free DNA becoming a recognized clinically practical biomarker. More research needs to be done to elucidate the basic aspects of circulating DNA, like its origin, function and significance of these nucleic acid molecules [18]. A well-recognized approach to quantify and analyze miscellaneous mutations in cancer should be set to better promote the clinical application of this very promising biomarker. This will also further benefit the treatment effect and survival of patients with various malignant neoplasms.

\section{References}

1. Utting M, Werner W, Dahse R, Schubert J, Junker K (2002) Microsatellite analysis of free tumor DNA in urine, serum, and plasma of patients: a minimally invasive method for the detection of bladder cancer. Clin Cancer Res 8: 35-40.

2. Anker $P$, Mulcahy $H$, Chen $X Q$, Stroun $M(1999)$ Detection of circulating tumour DNA in the blood (plasma/serum) of cancer patients. Cancer Metastasis Rev 18: $65-73$

3. Fleischhacker M, Schmidt B (2007) Circulating nucleic acids (CNAs) and cancer--a survey. Biochim Biophys Acta 1775: 181-232.

4. Mandelep, Metaisp (1948) CR Seances Soc Biol Fil 142: 241-243.

5. Tran Thi Ngoc Ha NTH, Lyre Anni Murao, Nguyen Thi Phuong Lan, Tran Thi Thuy, Ha Manh Tuan, et al.( 2011) Elevated levels of cell-free circulating DNA in patients with acute Dengue virus infection. Plos One 6: e25969.

6. Iriyama $\mathrm{C}$, Tomita $\mathrm{A}$, Hoshino $\mathrm{H}$, Adachi-Shirahata $\mathrm{M}$, Furukawa-Hibi $\mathrm{Y}$ et al. (2012) Using peripheral blood circulating DNAs to detect CpG global methylation status and genetic mutations in patients with myelodysplastic syndrome. Biochem Biophys Res Commun 419: 662-669.

7. Ibanez de Caceres I, Battagli C, Esteller M, Herman JG, Dulaimi E, et al. (2004) 
Tumor cell-specific BRCA1 and RASSF1A hypermethylation in serum, plasma, and peritoneal fluid from ovarian cancer patients. Cancer Res 64: 6476-6481.

8. Kwee S, Song MA, Cheng I, Loo L, Tiirikainen M (2012) Measurement of circulating cell-free DNA in relation to $18 \mathrm{~F}$-fluorocholine PET/CT imaging in chemotherapy-treated advanced prostate cancer. Clin Transl Sci 5: 65-70.

9. $\mathrm{CH}$ Huang MST, Chiung-Yuan Hsu, Huei-Wen Chen, Tzung-Dau Wang, Wei-Tien Chang (2012) Circulating cell-free DNA levels correlate with post resuscitation survival rates in out-of-hospital cardiac arrest patients. Resuscitation 83: 213-218.

10. van der Vaart M, Pretorius PJ (2008) Circulating DNA. Its origin and fluctuation. Ann N Y Acad Sci 1137: 18-26.

11. Stroun M, Lyautey J, Lederrey C, Olson-Sand A, Anker P (2001) About the possible origin and mechanism of circulating DNA apoptosis and active DNA release. Clin Chim Acta 313: 139-142.

12. van der Vaart M, Pretorius PJ (2007) The origin of circulating free DNA. Clin Chem 53: 2215.

13. Anker P, Stroun M, Maurice PA (1976) Spontaneous extracellular synthesis of DNA released by human blood lymphocytes. Cancer Res 36: 2832-2839.

14. Anker $P$, Stroun M, Maurice $P$ (1977) [Characteristics of nucleic acids excreted by non-stimulated normal human lymphocytes]. Schweiz Med Wochenschr 107: 1457

15. Kohler C, Barekati Z, Radpour R, Zhong XY (2011) Cell-free DNA in the circulation as a potential cancer biomarker. Anticancer Res 31: 2623-2628.

16. Laktionov PP, Tamkovich SN, Rykova EY, Bryzgunova OE, Starikov AV, et al (2004) Cell-surface-bound nucleic acids: Free and cell-surface-bound nucleic acids in blood of healthy donors and breast cancer patients. Ann N Y Acad Sci 1022: 221-227.

17. Tamkovich SN, Bryzgunova OE, Rykova EY, Permyakova VI, Vlassov VV, et al. (2005) Circulating nucleic acids in blood of healthy male and female donors. Clin Chem 51: 1317-1319.

18. van der Vaart M, Pretorius PJ (2010) Is the role of circulating DNA as a biomarker of cancer being prematurely overrated? Clin Biochem 43: 26-36.

19. Gordian E, Ramachandran K, Reis IM, Manoharan M, Soloway MS, et al (2010) Serum free circulating DNA is a useful biomarker to distinguish benign versus malignant prostate disease. Cancer Epidemiol Biomarkers Prev 19 1984-1991.

20. Pathak AK, Bhutani M, Kumar S, Mohan A, Guleria R (2006) Circulating cellfree DNA in plasma/serum of lung cancer patients as a potential screening and prognostic tool. Clin Chem 52: 1833-1842.

21. Wu TL, Zhang D, Chia JH, Tsao KH, Sun CF, et al. (2002) Cell-free DNA measurement in various carcinomas and establishment of normal reference range. Clin Chim Acta 321: 77-87.

22. Ellinger J, Albers P, Perabo FG, Müller SC, von Ruecker A, et al. (2009) CpG island hypermethylation of cell-free circulating serum DNA in patients with testicular cancer. J Urol 182: 324-329.

23. Zhang R, Shao F, Wu X, Ying K (2010) Value of quantitative analysis of circulating cell free DNA as a screening tool for lung cancer: a meta-analysis. Lung Cancer 69: 225-231.

24. Kamat AA, Baldwin M, Urbauer D, Dang D, Han LY, et al. (2010) Plasma cellfree DNA in ovarian cancer: an independent prognostic biomarker. Cancer 116 1918-1925.

25. Kamat AA, Bischoff FZ, Dang D, Baldwin MF, Han LY, et al. (2006) Circulating cell-free DNA: a novel biomarker for response to therapy in ovarian carcinoma. Cancer Biol Ther 5: 1369-1374.

26. Schwarzenbach H, Hoon DS, Pantel K (2011) Cell-free nucleic acids as biomarkers in cancer patients. Nat Rev Cancer 11: 426-437.

27. Jahr S, Hentze H, Englisch S, Hardt D, Fackelmayer FO, et al. (2001) DNA fragments in the blood plasma of cancer patients: quantitations and evidence for their origin from apoptotic and necrotic cells. Cancer Res 61: 1659-1665.

28. Anker P, Mulcahy H, Stroun M (2003) Circulating nucleic acids in plasma and serum as a noninvasive investigation for cancer: time for large-scale clinical studies? Int J Cancer 103: 149-152.

29. Norio lizuka IS, Toyoki M, Nozomi F, Toshiaki M, Markus S, et al. (2006) Hideo
Ishitsuka, Koichi Uchida, Shuji Terai, Kazuhiko Sakamoto, Takao Tamesa, Masaaki Oka: Elevated levels of circulating cell-free DNA in the blood of patients with hepatitis $C$ virus-associatd hepatocellular carcinoma. Anticancer Research 26:4713-4720.

30. Jiang Y, Pan SY, Xia WY, Chen D, Wang H, et al. (2012) Dynamic monitoring of plasma circulating DNA in patients with acute myeloid leukemia and its clinical significance. 20: 53-56.

31. Allen D, Butt A, Cahill D, Wheeler M, Popert R, et al. (2004) Role of cell-free plasma DNA as a diagnostic marker for prostate cancer. Ann $N$ Y Acad Sci 1022: $76-80$.

32. Goebel G, Zitt M, Zitt M, Müller HM (2005) Circulating nucleic acids in plasma or serum (CNAPS) as prognostic and predictive markers in patients with solid neoplasias. Dis Markers 21: 105-120.

33. Leon SA, Ehrlich GE,Shapiro B, Labbate VA (1977) Free DNA in the serum of rheumatoid arthritis patients. J Rheumatol. 4: 139-143.

34. Gautschi O, Bigosch C, Huegli B, Jermann M, Marx A, et al. (2004) Circulating deoxyribonucleic Acid as prognostic marker in non-small-cell lung cancer patients undergoing chemotherapy. J Clin Oncol 22: 4157-4164.

35. Gormally E HP, Caboux E, Airoldi L, Autrup H, Malaveille C, Dunning A, et al. (2004) Amount of DNA in plasma and cancer risk: a prospective study. Int $J$ Cancer 111: 746-749.

36. Goessl C (2003) Diagnostic potential of circulating nucleic acids for oncology. Expert Rev Mol Diagn 3: 431-442.

37. Anker P, Stroun M (2001) Tumor-related alterations in circulating DNA potential for diagnosis, prognosis and detection of minimal residual disease. Leukemia 15: 289-291.

38. Gormally E, Caboux E, Vineis P, Hainaut P (2007) Circulating free DNA in plasma or serum as biomarker of carcinogenesis: practical aspects and biological significance. Mutat Res 635: 105-117.

39. Vasioukhin V, Anker P, Maurice P, Lyautey J, Lederrey C, et al. (1994) Point mutations of the $\mathrm{N}$-ras gene in the blood plasma DNA of patients with myelodysplastic syndrome or acute myelogenous leukaemia. $\mathrm{Br} \mathrm{J}$ Haematol 86: 774-779.

40. Ryan BM, McManus RO, Daly JS, Keeling PW, Weir DG, et al. (2000) Serum mutant K-ras in the colorectal adenoma-to-carcinoma sequence. Implications for diagnosis, postoperative follow-up, and early detection of recurrent disease. Ann N Y Acad Sci 906: 29-30.

41. Mulcahy HE, Lyautey J, Lederrey C, Chen Xqi, Anker P, et al. (1998) K-ras gene mutations in the plasma of pancreatic patients. Clin Cancer Res 4: 271 275

42. Yamada T, Nakamori S, Ohzato H, Oshima S, Aoki T, et al. (1998) Detection of K-ras gene mutations in plasma DNA of patients with pancreatic adenocarcinoma: correlation with clinicopathological features. Clin Cancer Res 4: $1527-1532$.

43. De Schutter H, Spaepen M, Mc Bride WH, Nuyts S (2007) The clinical relevance of microsatellite alterations in head and neck squamous cell carcinoma: a critical review. Eur J Hum Genet 15: 734-741.

44. Schwarzenbach H, Müller V, Stahmann N, Pantel K (2004) Detection and characterization of circulating microsatellite-DNA in blood of patients with breast cancer. Ann N Y Acad Sci 1022: 25-32.

45. Ludovini V, Pistola L, Gregorc V, Floriani I, Rulli E, et al. (2008) Plasma DNA, microsatellite alterations, and p53 tumor mutations are associated with disease-free survival in radically resected non-small cell lung cancer patients: a study of the perugia multidisciplinary team for thoracic oncology. J Thorac Oncol 3: 365-373.

46. Taback B, O'Day SJ, Boasberg PD, Shu S, Fournier P, et al. (2004) Circulating DNA microsatellites: molecular determinants of response to biochemotherapy in patients with metastatic melanoma. J Natl Cancer Inst 96: 152-156.

47. Taback B, Fujiwara Y, Wang HJ, Foshag LJ, Morton DL, et al. (2001) Prognostic significance of circulating microsatellite markers in the plasma of melanoma patients. Cancer Res 61: 5723-5726.

48. Takagi R, Nakamoto D, Mizoe JE, Tsujii H (2007) LOH analysis of free DNA in the plasma of patients with mucosal malignant melanoma in the head and neck. Int J Clin Oncol 12: 199-204.

49. Rawnaq T, Schwarzenbach H, Schurr PG, Freise K, Brandl S, et al. (2011) 
Monitoring of loss of heterozygosity in serum microsatellite DNA among patients with gastrointestinal stromal tumors indicates tumor recurrence. J Surg Res 169: 31-35.

50. Kakimoto Y, Yamamoto N, Shibahara T (2008) Microsatellite analysis of serum DNA in patients with oral squamous cell carcinoma. Oncol Rep 20: 1195-1200.

51. Egger G, Liang G, Aparicio A, Jones PA (2004) Epigenetics in human disease and prospects for epigenetic therapy. Nature 429: 457-463.

52. Ehrlich M (2002) DNA methylation in cancer: too much, but also too little. Oncogene 21: 5400-5413.

53. Nakamoto D, Yamamoto N, Takagi R, Katakura A, Mizoe JE, et al. (2008) Detection of microsatellite alterations in plasma DNA of malignant mucosal melanoma using whole genome amplification. Bull Tokyo Dent Coll 49: 77-87.

54. Virmani AK, Rathi A, Sathyanarayana UG, Padar A, Huang CX, et al. (2001) Aberrant methylation of the adenomatous polyposis coli (APC) gene promoter $1 \mathrm{~A}$ in breast and lung carcinomas. Clin Cancer Res 7: 1998-2004.

55. Tsuchiya T, Tamura G, Sato K, Endoh Y, Sakata K, et al. (2000) Distinct methylation patterns of two APC gene promoters in normal and cancerous gastric epithelia. Oncogene 19: 3642-3646.

56. Rice JC Massy BKS, Futscher BW (1998) Aberrant methylation of the BRCA1 $\mathrm{CpG}$ island promoter is associated with decreased BRCA1 mRNA in sporadic breast cancer cells. Oncogene 17: 1807-1812.

57. Bian YS, Osterheld MC, Fontolliet C, Bosman FT, Benhattar J (2002) p16 inactivation by methylation of the CDKN2A promoter occurs early during neoplastic progression in Barrett's esophagus. Gastroenterology 122: 11131121.

58. Holst CR, Nuovo GJ, Esteller M, Chew K, Baylin SB, et al. (2003) Methylation of p16(INK4a) promoters occurs in vivo in histologically normal human mammary epithelia. Cancer Res 63: 1596-1601.

59. Chan KC, Lo YM (2007) Circulating tumour-derived nucleic acids in cance patients: potential applications as tumour markers. $\mathrm{Br} \mathrm{J}$ Cancer 96: 681-685.

60. Schwarzenbach H, Hoon DS, Pantel K (2011) Cell-free nucleic acids as biomarkers in cancer patients. Nat Rev Cancer 11: 426-437.

61. Shen L, Kantarjian H, Guo Y, Lin E, Shan J, et al. (2010) DNA methylation predicts survival and response to therapy in patients with myelodysplastic syndromes. J Clin Oncol 28: 605-613.

62. Kaneto H, Sasaki S, Yamamoto H, Itoh F, Toyota M, et al. (2001) Detection of hypermethylation of the $\mathrm{p} 16$ (INK4A) gene promoter in chronic hepatitis and cirrhosis associated with hepatitis B or C virus. Gut 48: 372-377.

63. Harder J, Opitz OG, Brabender J, Olschewski M, Blum HE, et al. (2008) Quantitative promoter methylation analysis of hepatocellular carcinoma, cirrhotic and normal liver. Int J Cancer 122: 2800-2804.

64. Belinsky SA, Nikula KJ, Palmisano WA, Michels R, Saccomanno G, et al. (1998) Aberrant methylation of $\mathrm{p} 16$ (INK4a) is an early event in lung cancer and a potential biomarker for early diagnosis. Proc Natl Acad Sci U S A 95 $11891-11896$

65. Hsieh CJ, Klump B, Holzmann K, Borchard F, Gregor M, et al. (1998) Hypermethylation of the p16INK4a promoter in colectomy specimens of patients with long-standing and extensive ulcerative colitis. Cancer Res 58 3942-3945.

66. Klump B, Hsieh CJ, Holzmann K, Gregor M, Porschen R (1998) Hypermethylation of the CDKN2/p16 promoter during neoplastic progression in Barrett's esophagus. Gastroenterology 115: 1381-1386.

67. Wilentz RE, Geradts J, Maynard R, Offerhaus GJ, Kang M, et al. (1998) Inactivation of the p16 (INK4A) tumor-suppressor gene in pancreatic duct lesions: loss of intranuclear expression. Cancer Res 58: 4740-4744.

68. Stéphanie V, Emilie LG, Doriane AG, Amelie P, Gilles F, et al. (2011) Seasonal variation in TP53 R249S-mutated serum DNA with aflatoxin exposure and hepatitis B virus infection. Environ Health Perspect 119: 1635-1640.

69. Mirza S, Sharma G, Parshad R, Srivastava A, Gupta SD et al. (2012) Clinical significance of promoter hypermethylation of ER-beta and RAR-beta2 in tumor and serum DNA in indian breast cancer patients. Ann Surg Oncol.

70. Philipp AB, Stieber P, Nagel D, Neumann J, Spelsberg F, et al. (2012) Prognostic role of methylated free circulating DNA in colorectal cancer. Int $\mathrm{J}$ Cancer.
71. Jones PA, Baylin SB (2007) The epigenomics of cancer. Cell 128: 683-692.

72. Herbst A, Rahmig K, Stieber P, Philipp A, Jung A, et al. (2011) Methylation of NEUROG1 in serum is a sensitive marker for the detection of early colorectal cancer. Am J Gastroenterol 106: 1110-1118.

73. deVos T, Tetzner R, Model F, Weiss G, Schuster M, et al. (2009) Circulating methylated SEPT9 DNA in plasma is a biomarker for colorectal cancer. Clin Chem 55: 1337-1346.

74. Ebert MP, Model F, Mooney S, Hale K, Lograsso J, et al. (2006) Aristalesslike homeobox-4 gene methylation is a potential marker for colorectal adenocarcinomas. Gastroenterology 131: 1418-1430.

75. Wallner M, Herbst A, Behrens A, Crispin A, Stieber P, et al. (2006) Methylation of serum DNA is an independent prognostic marker in colorectal cancer. Clin Cancer Res 12: 7347-7352.

76. Herbst A, Wallner M, Rahmig K, Stieber P, Crispin A, et al. (2009) Methylation of helicase-like transcription factor in serum of patients with colorectal cancer is an independent predictor of disease recurrence. Eur J Gastroenterol Hepatol 21: $565-569$.

77. Furuta J, Umebayashi Y, Miyamoto K, Kikuchi K, Otsuka F, et al. (2004) Promoter methylation profiling of 30 genes in human malignant melanoma. Cancer Sci 95: 962-968.

78. Hoon DS, Spugnardi M, Kuo C, Huang SK, Morton DL, et al. (2004) Profiling epigenetic inactivation of tumor suppressor genes in tumors and plasma from cutaneous melanoma patients. Oncogene 23: 4014-4022.

79. Worm J, Christensen C, Grønbaek K, Tulchinsky E, Guldberg P (2004) Genetic and epigenetic alterations of the APC gene in malignant melanoma. Oncogene 23: $5215-5226$.

80. Mirmohammadsadegh A, Marini A, Nambiar S, Hassan M, Tannapfel A, et al (2006) Epigenetic silencing of the PTEN gene in melanoma. Cancer Res 66: 6546-6552.

81. Patino WD, Susa J (2008) Epigenetics of cutaneous melanoma. Adv Dermato 24: $59-70$.

82. Tanemura A, Terando AM, Sim MS, van Hoesel AQ, de Maat MF, et al. (2009) $\mathrm{CpG}$ island methylator phenotype predicts progression of malignant melanoma. Clin Cancer Res 15: 1801-1807.

83. Gandhi MK (2006) Epstein-Barr virus-associated lymphomas. Expert Rev Anti Infect Ther 4: 77-89.

84. Gallagher A, Armstrong AA, MacKenzie J, Shield L, Khan G, et al. (1999) Detection of Epstein-Barr virus (EBV) genomes in the serum of patients with EBV-associated Hodgkin's disease. Int J Cancer 84: 442-448.

85. Gandhi MK, Lambley E, Burrows J, Dua U, Elliott S, et al. (2006) Plasma Epstein-Barr virus (EBV) DNA is a biomarker for EBV-positive Hodgkin's lymphoma. Clin Cancer Res 12: 460-464.

86. Au WY, Pang A, Choy C, Chim CS, Kwong YL (2004) Quantification of circulating Epstein-Barr virus (EBV) DNA in the diagnosis and monitoring of natural killer cell and EBV-positive lymphomas in immunocompetent patients. Blood 104: 243-249.

87. Lin JC, Wang WY, Chen KY, Wei YH, Liang WM, et al. (2004) Quantification of plasma Epstein-Barr virus DNA in patients with advanced nasopharyngea carcinoma. N Engl J Med 350: 2461-2470.

88. Jones K, Nourse JP, Keane C, Crooks P, Gottlieb D, et al. (2012) Tumorspecific but not nonspecific cell-free circulating DNA can be used to monitor disease response in lymphoma. Am J Hematol 87: 258-265.

89. de Kok JB, Hendriks JC, van Solinge WW, Willems HL, Mensink EJ, et al. (1998) Use of real-time quantitative PCR to compare DNA isolation methods. Clin Chem 44: 2201-2204.

90. Stemmer C, Beau-Faller M, Pencreac'h E, Guerin E, Schneider A, et al. (2003) Use of magnetic beads for plasma cell-free DNA extraction: toward automation of plasma DNA analysis for molecular diagnostics. Clin Chem 49: 1953-1955.

91. Brisson-Noel A, Aznar C, Chureau C, Nguyen S, Pierre C, et al. (1991) Diagnosis of tuberculosis by DNA amplification in clinical practice evaluation. Lancet 338: 364-366.

92. Kramvis A, Bukofzer S, Kew MC (1996) Comparison of hepatitis B virus DNA extractions from serum by the QIAamp blood kit, GeneReleaser, and the phenol-chloroform method. J Clin Microbiol 34: 2731-2733. 
Citation: Jin D, Xie S, Mo Z, Liang Y, Guo B, et al. (2012) Circulating DNA-Important Biomarker of Cancer. J Mol Biomarkers Diagn S2:009. doi:10.4172/2155-9929.S2-009

93. Xue X, Teare MD, Holen I, Zhu YM, Woll PJ (2009) Optimizing the yield and utility of circulating cell-free DNA from plasma and serum. Clin Chim Acta 404: 100-104.

94. Juulia J, Marja J,Terho L, Antti H, Mikko H (2012) Circulating cell-free DNA is associated with mortality and inflammatory markers in nonagenarians: The Vitality 90+ Study. Exp Gerontol. 47: 372-378.

95. Mal'shakova VS, Pyshnyi DV, Bondar AA, Vlassov VV, Laktionov PP (2008) Isolation and sequencing of short cell-surface-bound DNA. Ann N Y Acad Sci 1137: 47-50.

96. Elena Yu Rykova PPL, Tatyana E Skvortsova, Andrey V Starikov, Nina P Kuznetsova, Valentin V Vlassov (2006) Extracellular DNA in breast cancer. Annals of the New York Academy of Sciences 1022: 217-220.

97. Yulia K, Rebecca KM, Nathan L, Robert WC, Blaire B et al. (2008) Massively parallel bisulphite pyrosequencing reveals the molecular complexity of breast cancer-associated cytosine-methylation patterns obtained from tissue and serum DNA. Genome Res 18: 19-29.

98. Chiu RW, Lo YM (2012) Noninvasive prenatal diagnosis empowered by highthroughput sequencing. Prenat Diagn 32: 401-406.

99. Margulies M, Egholm M, Altman WE, Attiya S, Bader JS, et al. (2005) Genome sequencing in microfabricated high-density picolitre reactors. Nature 437: $376-$ 380.
100. Goldberg SM, Johnson J, Busam D, Feldblyum T, Ferriera S, et al. (2006) A Sanger/pyrosequencing hybrid approach for the generation of high-quality draft assemblies of marine microbial genomes. Proc Natl Acad Sci U S A 103 11240-11245.

101. Wicker T, Schlagenhauf E, Graner A, Close TJ, Keller B, et al. (2006) 454 sequencing put to the test using the complex genome of barley. BMC Genomics 7: 275 .

102. Dennis Lo Y, Chiu RW (2011) Plasma nucleic acid analysis by massively parallel sequencing: pathological insights and diagnostic implications. J Pathol 225: 318-323.

103. Diehl F, Schmidt K, Choti MA, Romans K, Goodman S, et al. (2008) Circulating mutant DNA to assess tumor dynamics. Nat Med 14: 985-990.

104. Hampton T (2007) Methods to detect circulating tumor DNA may help early diagnosis of cancer. JAMA 298: 1993-1994.

105.Diehl F, Li M, Dressman D, He Y, Shen D, et al. (2005) Detection and quantification of mutations in the plasma of patients with colorectal tumors. Proc Natl Acad Sci U S A 102: 16368-16373.

106. Laken SJ, Jackson PE, Kinzler KW, Vogelstein B, Strickland PT, et al. (1998) Genotyping by mass spectrometric analysis of short DNA fragments. Nat Biotechnol 16: 1352-1356.
This article was originally published in a special issue, Cancer Biomarkers handled by Editor(s). Dr. Sudhir Srivastava, Cancer Biomarkers Research Group, National Institute of Health, USA; Dr. Shou-Jiang Gao, The University of Texas Health Science Centre at San Antonio, USA; Dr. Kenneth Maiese, University of Medicine \& Dentistry of New Jersey, New Jersey Medical School, USA 